\title{
THE MAIN FEATURES OF PROVIDING EMPLOYMENT FOR YOUNG PEOPLE WITH DISABILITIES IN UZBEKISTAN
}

\author{
Abdullo Abdukhalilov \\ Doctor Of Philosophy In Sociology (Phd), Associate Professor, National University Of Uzbekistan Named After Mirzo Ulugbek, \\ Uzbekistan
}

Indira Khudaykulova

Master Student, National University Of Uzbekistan Named After Mirzo Ulugbek, Uzbekistan

\section{ABSTRACT}

In this article, the main features of employment of young people with disabilities in Uzbekistan are analyzed. Based on the findings of the study, the conclusion and disallows were made.

KEYWORDS:- Disabled person, inclusive higher education, labor market, Disabled rights, graduates with disabilities

\section{INTRODUCTION}

The draft resolution of the President of the Republic of Uzbekistan "On the state order for the creation of new jobs and the promotion of employment in 2021" has been published. The purpose of the draft resolution is to comprehensively promote the increase of employment and incomes of the population, the introduction of new mechanisms to promote the employment of the unemployed, especially youth and women, graduates entering the labor market for the first time, creating favorable conditions for attracting the needy population to work, as well as stimulating the activities of business entities creating new jobs.

457127 jobs should be created in the Republic of Uzbekistan in 2021. In solving this problem, various stakeholders, including regional authorities, entrepreneurship, political and public organizations, educational institutions, will take part.

The decree of the president of Uzbekistan "on measures to radically improve the system of state support of Persons with Disabilities", adopted onberember 1, 2017, provides for measures to provide benefits for persons with disabilities for the entrance examination to higher education institutions. That is, the state applications a measure of positive disiminimination, deviating from the rule of creating equal conditions for all, that is, it provides for strict special benefits that substitute a deficit in terms of disability, race, gender. 
The serious problem of university graduates in finding a job is that they are unable to analyze the real situation in the labor market and lack of opinions about their employment prospects and technologies. This problem is of particular importance for persons with disabilities.

The main way to solve this problem is now inclusive higher education. Inclusive is an approach to the organization of the process of higher education, in which all young people, regardless of their physical, mental and other characteristics, are taught together at the University. Persons with disabilities receive education along with their peers, but at the same time their special educational needs are taken into account, including support in the field of providing the necessary employment.

In the inclusive higher education system, higher education institutions should support the employment of graduates with disabilities. First of all, it is necessary and sufficient to help the future graduate to determine his professional preferences in time, to assess himself and the possibility of professional self-awareness and professional self-esteem, which includes the psychological and psychophysical qualities of a person, if he has special knowledge, skills and qualifications, to achieve a socially acceptable work efficiency of a person, in addition, Factors of professional competence are abilities that are significant for the implementation of appropriate professional activities, as well as positive professional motivation.

Analysis and results

The purpose of monitoring the labor market (quota jobs) is to successfully solve the problem of employment of graduates with disabilities who have graduated from higher education programs in a higher institution.

To achieve this goal, it is necessary to solve the following tasks:

- Study of the regional labor market and assessment of the state of the labor market for people working with young people with disabilities;

- Creating conditions conducive to expanding employment opportunities for graduates with disabilities based on their individual needs and rehabilitation programs;

- Formation of a data bank (register) of vacancies for graduates with disabilities;

- Formation of a data bank (register) of students and graduates with youth with disabilities, a database of employers' organizations, personnel services, employment centers;

- Development of social partnership for the purpose of employment of graduates with disabilities;

- A variety of sources of information about vacancies for people with disabilities;

On December 1, on the eve of the International Day of Disabled People (December 3), President of Uzbekistan Shavkat Mirziyoyev signed a decree "on measures to radically improve the system of state support for persons with disabilities." The document was adopted by the commission for the preparation of proposals aimed at radically improving the system of state support for persons with disabilities, after a comprehensive and in-depth study of the state of affairs in the field of early detection and prevention of disability, provision of medical and social assistance to persons with disabilities, their vocational training and employment.

More than 710 thousand disabled people live in Uzbekistan. Many disabled people face various difficulties in everyday life, which negatively affects their active participation in the political, social, economic and cultural life of the country, 
the official commentary to the decree says.

Practical activities are being organized to prepare for the ratification of the UN Convention on the Rights of Persons with Disabilities. A draft law "on the rights of persons with disabilities" will be developed. Changing the attitude of people to people with disabilities, informing others about their full and equal participation in society is an extremely important and priority step in solving the pressing problems of people with disabilities. For this purpose, the concept of "disabled person" is being withdrawn from circulation, and taking into account the fact that this is primarily a person, the generally recognized term "person with a disability" is being introduced.

In the decree, the following main directions of improvement of the system of state support of persons with disabilities were defined:

- to prevent discrimination on the sign of disability, to ensure equal conditions in the realization of the rights, freedoms and legitimate interests of persons with disabilities and the inevitability of liability for their violation;

- national legislation on the implementation of universally recognized international norms and standards in the field of ensuring the rights of persons with disabilities;

- $\quad$ to increase the level and quality of medical and social assistance to persons with disabilities by expanding access to hightech specialized medical and social assistance;

- to create the necessary conditions for interaction of persons with disabilities with family, society and the state, their being in a comfortable environment, free use of urban passenger, social and other infrastructure facilities;
- improving the inclusive education and employment system, which ensures the involvement and active participation of persons with disabilities in the socioeconomic life of the society, etc.

In order to widely stimulate the employment of persons with disabilities, as well as create conditions for engaging in entrepreneurial activity by persons with disabilities themselves, from January 1, 2018, a preferential tax rate is established for persons with disabilities of groups I and II engaged in individual entrepreneurship, as well as individual entrepreneurs employing persons with disabilities of groups I and II as employees.

In order to increase the literacy of persons with disabilities, special courses on teaching the Braille alphabet on the basis of secondary schools are organized in the Centers of Regions and districts.

Starting from the 2018/2019 academic year, additional two-percent quotas are introduced for persons with disabilities from the total number of admission of applicants to higher educational institutions.

The activities of the universities on the employment of graduates with disabilities and support after graduation should be conducted in the following directions:

- Monitoring the quota of permanent jobs;

- $\quad$ Build vocational school-oriented jobs with students and parents, including employment market monitoring datataking into account recommended vacancies in the region;

- Orientation of prospective students towards higher education in demand;

- Interaction of educational institutions with employers to more accurately characterize the requirements for higher professional 
CURRENT RESEARCH JOURNAL OF PEDAGOGICS 2(10): 67-70,

October 2021 DOI: https://doi.org/10.37547/pedagogics-crjp-02-10-13

ISSN 2767-3278

(C)2021 Master Journals

\section{Crossref doi) google}

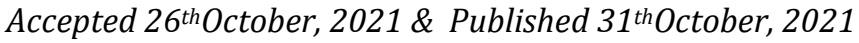

qualifications and to declare vacancies for a particular position;

- $\quad$ Conclusion of contracts with employers on Organization of internship of students with disabilities;

- $\quad$ Retraining graduates with disabilities taking into account the peculiarities of the labor market there is an increase.

There are no global differences in sociopsychological well-being parameters between disabled students and non-disabled students, which creates favorable conditions for further expansion and development of inclusive higher education. Belonging to one socio-typological and age group, as well as the general type of leadership activity, leads to the fact that all students experience the same or similar problems. The successful solution to the problem of employment of young people with disabilities is the development of inclusive higher education in the higher education system.

\section{Conclusion}

In conclusion, according to the results of the study, it is necessary to carry out the following tasks in the employment of young people with disabilities:

1. creating conditions conducive to expanding employment opportunities for young people with disabilities, taking into account their individual needs and rehabilitation programs;

2. vocational orientation and employment in accordance with the needs and interests of young people with disabilities;

3. increase their competitiveness in the labor market as a result of increasing the standard and quality of life of persons with disabilities.

\section{REFERENCES}

1. Nishanbayeva, E.Z., and Abdukhalilov, A.A. (2020). THE ROLE OF SOCIAL PARTNERSHIP IN THE DEVELOPMENT OF INCLUSIVE EDUCATION. Journal of Social Research, (SPECIAL 1).

2. Dilmurod Yusupov "Inclusive Higher Education" March 4, 2019, Gazeta.uz website;

3. Akimenko, A. K. (2015). Training of competitive specialists in inclusive education. Inclusive education: results , experience and prospects. Collection of materials of the III International Scientific and Practical Conference (pp.392-396);

4. Almarghani, E. M., Mijatovic, I. Factors affecting student engagement in heis-it is all about good teaching. Teaching in higher education, 2017, pp. 1-17. doi:10.1080/13562517.2017.1319808.;

5. Decree of the president of Uzbekistan Shavkat Mirziyoyev"on measures to radically improve the system of state support of persons with disabilities.

6. Grishaeva, S. A., Mitrofanova, A. E., \& Mitrofanova, E. A. (2018). Professional diagnostics and employment of students with disabilities. Bulletin of the University, (12).;

7. Kantor, V. Z. (2019). Inclusive higher education: socio-psychological well-being of students. Education and Science, 21(2).;

8. Abdukhalilov, A. A. (2014). Models of understanding disability in the social policy of the state. In Collections of conferences of SIC Sociosphere (No. 34, pp. 82-84). Vedecko vydavatelské centrum Sociosféra-CZ sro. 